\title{
Modeling Dynamic Exchange of Gaseous Elemental Mercury at Polar Sunrise
}

\author{
Ashu P. Dastoor, Didier Davignon. Nicolas Theys, Michel Van Roozendael, Alexandra Steffen \\ and Parisa A. Ariya
}

\begin{abstract}
At polar sunrise, gaseous elemental mercury (GEM) undergoes an exceptional dynamic exchange in the air and at the snow surface during which GEM can be rapidly removed from the atmosphere (the so-called atmospheric mercury depletion events (AMDEs)) as well as re-emitted from the snow within a few hours to days in the Polar Regions. Although high concentrations of total mercury in snow following AMDEs is well documented, there is very little data available on the redox transformation processes of mercury in the snow and the fluxes of mercury at the air/snow interface. Therefore, the net gain of mercury in the Polar Regions as a result of AMDEs is still an open question. We developed a new version of the global mercury model, GRAHM, which includes for the first time bidirectional surface exchange of GEM in Polar Regions in spring and summer by developing schemes for mercury halogen oxidation, deposition, and re-emission. Also for the first time, GOME satellite data-derived boundary layer concentrations of $\mathrm{BrO}$ have been used in a global mercury model for representation of halogen mercury chemistry. Comparison of model simulated and measured atmospheric concentrations of GEM at Alert, Canada, for 3 years (2002-2004) shows the model's capability in simulating the rapid cycling of mercury during and after AMDEs. Brooks et al. (1) measured mercury deposition, re-emission, and net surface gain fluxes of mercury at Barrow, AK, during an intensive measurement campaign for a 2 week period in spring (March 25 to April 7, 2003). They reported $1.7,1.0 \pm 0.2$, and $0.7 \pm 0.2 \mu \mathrm{g} \mathrm{m}^{-2}$ deposition, re-emission, and net surface gain, respectively. Using the optimal configuration of the model, we estimated $1.8 \mu \mathrm{g} \mathrm{m}^{-2}$ deposition, $1.0 \mu \mathrm{g} \mathrm{m}^{-2}$ re-emission, and $0.8 \mu \mathrm{g} \mathrm{m}^{-2}$ net surface gain of mercury for the same time period at Barrow. The estimated net annual accumulation of mercury within the Arctic Circle north of $66.5^{\circ}$ is $\sim 174 \mathrm{t}$ with $\pm 7 \mathrm{t}$ of interannual variability for 2002-2004 using the optimal configuration. We estimated the uncertainty of the model results to the $\mathrm{Hg} / \mathrm{Br}$ reaction rate coefficient to be $\sim 6 \%$. Springtime is clearly demonstrated as the most active period of mercury exchanges and net surface gain ( $\sim 46 \%$ of annual accumulation) in the Arctic.
\end{abstract}

\section{Introduction}

The Arctic environment is now receiving at least three times more atmospheric mercury compared to preindustrial time (2). During atmospheric mercury depletion events (AMDEs), gaseous elemental mercury (GEM) can be converted to hygroscopic mercury species (reactive gaseous mercury (RGM) and total particulate mercury (TPM)) in less than 1 day and deposited to snow/ice (3). Goodsite et al. (4) showed that AMDEs could be explained by gasphase oxidation of $\mathrm{Hg}(0)$ by $\mathrm{Br}$ atoms based on theoretical kinetics. Experimental studies also demonstrate that reactions of GEM with $\mathrm{BrO}$ and $\mathrm{Br}$ are the most likely mechanism of AMDEs in the Polar Regions (5-7). Although, depletion of GEM and high concentrations of total mercury in snow related to AMDEs have been measured extensively, the postdepositional fate of mercury in snow is not well known $\underline{(3,8)}$. Above normal concentrations of GEM have been measured following AMDEs, suggesting re-emission of newly deposited mercury from snow $(3,9)$. Rapid reduction of total mercury and an increase in volatile mercury concentrations were measured in the Arctic and sub-Arctic snowpacks during AMDEs $(10,11)$. Poulain et al. (8) studied mercury concentrations, partitioning, and speciation in snow during snowmelt in the Arctic. They found low mercury concentrations in surface snow, high mercury concentrations at the depth of the snow/sea ice interface, and an increase in the total mercury concentrations in surface water at the sea ice edges due to melting snowpacks and suggested that $\mathrm{Hg}$ deposited through AMDEs in the early spring is partly lost to the atmosphere before snowmelt and the sea ice/snow interface constitutes a site for $\mathrm{Hg}$ accumulation.

Thus far, three mercury modeling studies have attempted the simulation of AMDEs in the Arctic $(6,12,13)$. Due to the lack of adequate understanding of chemical and physical processes related to AMDEs at the time, these studies used simple parametrizations for GEM depletion in the Polar boundary layer in the springtime and did not include mercury halogen reactions implicated in AMDEs explicitly in addition to the global tropospheric mercury 
This is the peer reviewed version of the following article: [Dastoor AP, Davignon D, Theys N, Van Roozendael M, Steffen A, Ariya PA. Modeling dynamic exchange of gaseous elemental mercury at polar sunrise. Environ Sci Technol. 2008 Jul 15;42(14):5183-8. doi: 10.1021/es800291w. PMID: 18754367.], which is available at: https://pubs.acs.org/doi/abs/10.1021/es800291w

chemistry (14). Also, the dynamic surface exchange of mercury due to reduction and re-emission of mercury from snowpacks was not represented in these studies. Although, these studies simulated mercury depletion during springtime, the high concentration episodes of GEM following AMDEs and above average concentrations of GEM in summertime observed at some Arctic locations were not simulated. These studies provide an upper limit of the contribution of AMDEs to mercury accumulation in snow in Polar Regions. In an effort to advance the understanding of mercury cycling between the atmosphere and the surface in the Polar Regions during the spring and summer and assess the role of AMDEs in mercury accumulation, we developed a new version of Environment Canada's Global/Regional Atmospheric Heavy Metals Model (GRAHM) which includes parametrizations for the halogen-mediated mercury chemistry, deposition, and re-emission of mercury during spring and summer in the Polar Regions.

\section{Model Description}

GRAHM is an Eulerian, multiscale atmospheric model which simulates all meteorological dynamical and physical processes and mercury-related physicochemical processes in a single system. A general description of the model including tropospheric mercury chemistry and evaluation was previously published $(6,15)$. The model simulates transport, transformation, and surface exchange of three mercury species, namely, GEM, RGM, and TPM. For this study, the anthropogenic mercury emissions were updated to year 2000 (16). Terrestrial and oceanic emissions of GEM from direct natural sources and previously deposited mercury were introduced based on the global mercury budget study by Mason and Sheu (17). Land-based natural emissions were spatially distributed according to the natural enrichment of mercury, and re-emissions were distributed according to the distribution of total deposition of mercury for historic years. Oceanic emissions in the model are spatially distributed according to the deposition and primary production distribution. Seasonal and diurnal dependence is added to both land and oceanic emissions as a function of solar irradiance.

Laboratory and theoretical research indicate that the GEM oxidation during AMDEs is a gas-phase oxidation process caused by halogens to form RGM $\underline{(4,5)}$. RGM can remain in the gas phase or adsorb onto aerosols present in the air due to its hygroscopic properties (5). RGM and TPM both have been measured with varying ratios during AMDEs in the Arctic $(1,9,11)$. At Alert, Nunavut, and Churchill, Manitoba, high concentrations of TPM are observed at the beginning of spring and high concentrations of RGM later in the spring, whereas RGM is dominant at the Barrow, AK site. The ratios of RGM and TPM likely depend on the age of the air mass and presence of aerosols in the Arctic environment. In laboratory studies Ariya et al. $(5,6)$ examined the reactions of GEM with atomic and molecular halogens $\left(\mathrm{Cl}_{2}, \mathrm{Cl}, \mathrm{Br} 2, \mathrm{Br}\right.$, and $\left.\mathrm{BrO}\right)$ and concluded that $\mathrm{Br}$ and $\mathrm{BrO}$ are the most efficient reactants in oxidizing GEM $\left(\mathrm{Br}, k=(3.2 \pm 0.3) \times 10^{-12} \mathrm{~cm}^{3}\right.$ molecule ${ }^{-1} \mathrm{~s}^{-1} ; \mathrm{BrO}, 1.0 \times 10^{-15} \leq k \leq 1.0 \times$ $10^{-13} \mathrm{~cm}^{3}$ molecule $\mathrm{e}^{-1} \mathrm{~s}^{-1} ; k$ is the reaction rate coefficient). The GEM-Br reaction mechanism has been examined in several other experimental as well as theoretical studies with rate coefficients ranging from $1.1 \times 10^{-12}$ to $3.6 \times$ $10^{-13} \mathrm{~cm}^{3}$ molecules ${ }^{-1} \mathrm{~s}^{-1}(7)$. The GEM-Br reaction rate measured by Donohoue et al. (7) represents the lower end of the rates reported in the literature. Similar to the Polar Regions, diurnally varying elevated concentrations of RGM were also observed in the remote marine boundary layer (MBL), suggesting RGM production photochemically by reactions with halogens liberated from sea-salt particles $(18)$. Halogen oxidation of mercury over oceans can potentially reduce the lifetime of GEM and its long-range transport to the Polar Regions. On the other hand, given that the lifetime of RGM is on the order of few days (19), RGM formed over the high-latitude oceans can be transported and deposited in the Polar Regions. To account for these possible impacts, we extended the chemical mechanism in GRAHM to include GEM oxidation by halogen species in the Polar Regions as well as in the MBL. We adapted reaction rate coefficients from Ariya et al. $(5,6)$ for GEM reactions with $\mathrm{BrO}, \mathrm{Br}_{2}, \mathrm{Cl}$, and $\mathrm{Cl}_{2}$. For the GEM-Br reaction, we performed model simulations using reaction rate coefficients from Ariya et al. (5) and Donohoue et al. (7). Model simulated GEM oxidation during AMDEs was found to be better correlated with observations (at Alert) using the faster reaction rate reported by Ariya et al. (5). Therefore, we adapted the Ariya et al. (5) GEM-Br reaction rate coefficient for the optimal configuration of the model for this study. Since GEM-Br reaction is a significant reaction in producing AMDEs, additional model simulations were performed using the Donohoue et al. (7) reaction rate coefficient to estimate the uncertainty in model results. We assumed part of the oxidation product of mercury reactions by halogens as RGM and part as TPM in the absence of full understanding of the heterogeneous chemistry of mercury. Since the dry deposition velocities of RGM and TPM are much larger compared to GEM and both RGM and TPM are readily deposited to snow, lack of accuracy in partitioning between RGM and TPM is expected to have a small impact on the deposition estimates of mercury to the snow (19). 
This is the peer reviewed version of the following article: [Dastoor AP, Davignon D, Theys N, Van Roozendael M, Steffen A, Ariya PA. Modeling dynamic exchange of gaseous elemental mercury at polar sunrise. Environ Sci Technol. 2008 Jul 15;42(14):5183-8. doi: 10.1021/es800291w. PMID: 18754367.], which is available at: https://pubs.acs.org/doi/abs/10.1021/es800291w

The total column $\mathrm{BrO}$ values inferred from GOME (Global Ozone Monitoring Experiment) satellite observations provide evidence of enhanced $\mathrm{BrO}$ concentrations (so-called bromine explosion) in the polar boundary layer during springtime over sea ice and along the coast lines $\underline{(20)}$. Sources and processes responsible for bromine liberation in the Arctic boundary layer are not fully understood. Sea-salt aerosols, sea-salt deposits on snow, new sea-ice surfaces, and frost flowers have been suggested as sources (3). In a modeling study, Lehrer et al. (21) concluded that the availability of sea salts on surface sea ice, sunlight, and the boundary layer capped by a strong temperature inversion were necessary conditions for bromine explosion. In the absence of a complete understanding of bromine activation sources and chemistry in Polar Regions, we introduced GOME-derived $\mathrm{Br} / \mathrm{BrO}$ concentrations into the boundary layer of the model as a first step. Theys et al. (22) estimated tropospheric $\mathrm{BrO}$ amounts over polar and midlatitudes regions by combining total $\mathrm{BrO}$ columns from GOME (available for years 1996-2002) with stratospheric $\mathrm{BrO}$ concentrations calculated by a $3 \mathrm{D}$ chemical transport model. We subtracted a constant tropospheric background concentration of $\mathrm{BrO}$ from the total tropospheric $\mathrm{BrO}$ estimates to determine the total boundary layer BrO for years 1996-2002 (20). The general structure of the GOME-derived polar boundary layer $\mathrm{BrO}$ distribution for each month was found to be very consistent from year to year. Small interannual variance and localized structure of high $\mathrm{BrO}$ concentrations imply that there are preferential source regions of $\mathrm{BrO}$ in the Polar Regions and that $\mathrm{BrO}$ has a short lifetime, preventing its transport from the source region. Monthly averaged boundary layer $\mathrm{BrO}$ columns were derived from years 1996 to 2002 to filter out the interannual variance. Observations reveal that the enhanced $\mathrm{BrO}$ is confined to the boundary layer with a nearly constant mixing ratio (23). BrO concentrations within the boundary layer were calculated with the assumption of a constant mixing ratio using time-dependent boundary layer height. It should be pointed out that there are several sources of uncertainties in our estimates of boundary layer $\mathrm{BrO}$ concentrations such as the inherent difficulties of GOME $\mathrm{BrO}$ retrievals, model errors in stratospheric $\mathrm{BrO}$ estimates, and assumption of constant free tropospheric $\mathrm{BrO}$ background. Nonetheless, this procedure provides a reasonable and best estimate of the spatial and temporal distribution of boundary layer $\mathrm{BrO}$ in the model. The current understanding of $\mathrm{BrO}$ formation is either via the gasphase reactions of $\mathrm{Br}$ with $\mathrm{O}_{3}$ or through molecules generated through heterogeneous mechanisms, following photolysis such as $\mathrm{HOBr}$, and $\mathrm{BrCl}$, generating $\mathrm{Br}$ radical and eventually $\mathrm{BrO}$. It has been suggested that $\mathrm{Br}$ radicals are indeed a direct precursor for $\mathrm{BrO}$ generation and that the formation and destruction cycles of $\mathrm{Br}$ and $\mathrm{BrO}$ are closely linked together (24). We thus assumed the spatial distribution of $\mathrm{Br}$ to be similar to $\mathrm{BrO}$ in the Polar Regions and scaled it to provide peak concentrations of $\mathrm{Br}$ in the range from $10^{6}$ to $10^{8}$ molecules $\mathrm{cm}^{-3}(25)$. The concentrations of halogen species in MBL were parametrized as a function of monthly averaged sea-salt distribution simulated by a global model $(26,27)$. Since reactive halogens are photolytically produced, solar radiation reaching the boundary layer including the influence of cloud optical depth was used to parametrize the temporal variation of concentrations of all halogen species in the Polar Regions and the MBL $\underline{(1,27)}$.

There is very limited data available on the redox transformation processes and partitioning of mercury in the snowpack (8). In temperate regions, Lalonde et al. (28) showed that within $24 \mathrm{~h} \sim 50 \%$ of the newly deposited mercury could be photoreduced to GEM and recycled back to the atmosphere. In an high Arctic snowpack study, Poulain et al. (10) observed a large increase in total $\mathrm{Hg}$ concentrations in the surface snow during an AMDE which subsequently decreased by $92 \%$ within 2 days after the event due to production of volatile mercury (GEM) by photoreduction. They observed no increase in the total mercury concentrations in the deeper snow and concluded that the loss of total mercury in surface snow results in snow to air evasion of mercury. They further found evidence of photoinduced oxidation of newly photoproduced GEM. Several organic molecules and halides in the surface snow were detected that could act as oxidants of GEM. Oxidation of GEM in snowmelt samples spiked with $\mathrm{Cl}^{-}$was also observed by Lalonde et al. (29). Both studies suggest that due to the presence of oxidative molecules in the marine/coastal polar surface snow during springtime, the re-emission of deposited mercury through reduction is restricted because of the reoxidation and thus could lead to accumulation of mercury in these environments. On the basis of these studies, we assumed that the re-emission of mercury occurs only from the newly deposited mercury in the surface snow in the presence of solar radiation. In the absence of a sufficient understanding of the redox chemistry in snow, we developed a dynamic parametrization of the re-emission rate of mercury from snow in the Polar Regions assuming it to be a function of newly accumulated mercury in snow and modulated by the solar flux at the surface and the surface temperature. The solar flux reaching the surface is calculated as described by Fouquart and Bonnel (30), which includes attenuation by absorbing gases, aerosols, and clouds in the atmosphere. 
This is the peer reviewed version of the following article: [Dastoor AP, Davignon D, Theys N, Van Roozendael M, Steffen A, Ariya PA. Modeling dynamic exchange of gaseous elemental mercury at polar sunrise. Environ Sci Technol. 2008 Jul 15;42(14):5183-8. doi: 10.1021/es800291w. PMID: 18754367.], which is available at: https://pubs.acs.org/doi/abs/10.1021/es800291w

\section{Results and Discussion}

The model resolution for this study was $5^{\circ} \times 5^{\circ}$ in the horizontal and 28 levels up to $10 \mathrm{mb}$ in the vertical with higher resolution in the boundary layer. Model simulations were performed for the years 2002-2004 with an initial spin-up for three years with the above configuration. Although inclusion of the new processes in the GRAHM model is expected to have an impact on the mercury cycling in the Polar Regions in spring and summer, the new configuration of the model was first evaluated against the globally observed data. Available ambient GEM, RGM, and TPM measurement data was compiled by Selin et al. (31) in a recent modeling study. The mercury budgets in various compartments in the model were found to be well balanced. North to South gradient of ambient GEM concentrations over the Atlantic and Pacific oceans was found to be improved in this version of the model compared to the previous version as a result of addition of halogen mercury chemistry in the MBL. 
This is the peer reviewed version of the following article: [Dastoor AP, Davignon D, Theys N, Van Roozendael M, Steffen A, Ariya PA. Modeling dynamic exchange of gaseous elemental mercury at polar sunrise. Environ Sci Technol. 2008 Jul 15;42(14):5183-8. doi: 10.1021/es800291w. PMID: 18754367.], which is available at: https://pubs.acs.org/doi/abs/10.1021/es800291w

Atmospheric mercury measurements have been conducted in the Arctic at Alert, Barrow, Amderma, Ny-Alesund, and Station Nord (3). The longest record of GEM measurements in the Arctic is available at Alert, Nunavut, which has been continuous since 1995. Therefore, detailed evaluation of the new model schemes was performed at Alert for 3 years (2002-2004). The model is also evaluated at Amderma, Russia, where GEM data is available for
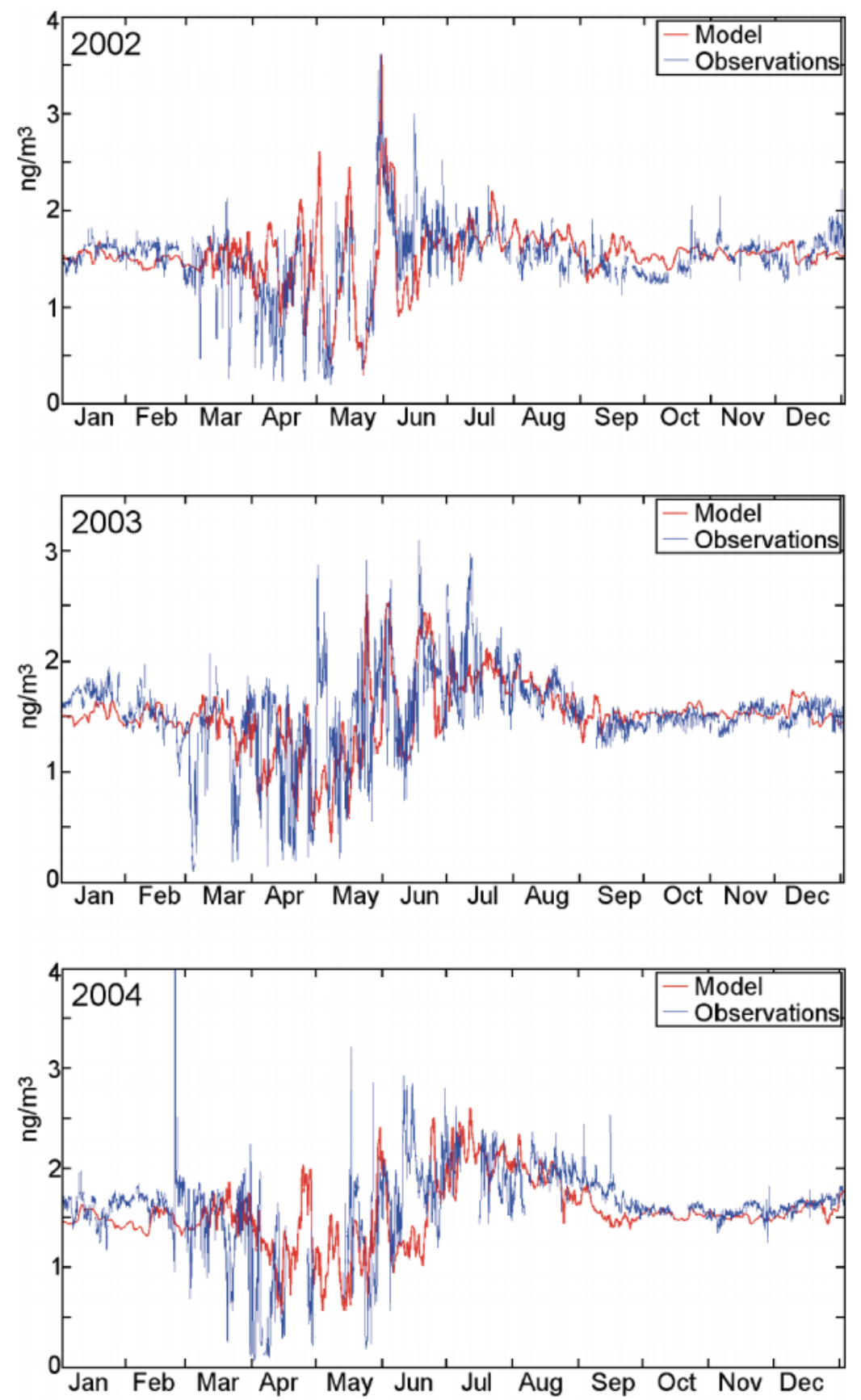

\section{FIGURE 1. Model simulated and measured concentrations of GEM (ng of standard $\mathrm{m}^{-3}$ ) at Alert, Canada, for years 2002 (top), 2003 (middle), and 2004 (bottom).}

2001/2002. A mass balance study for $\mathrm{Hg}$ in the springtime at Barrow was recently presented by Brooks et al. (1) for a 2 week period. We compared their data with the model simulated mass balance at Barrow. Model simulated GEM and RGM air concentrations at other locations are found to be in the same range as those reported in the limited 
This is the peer reviewed version of the following article: [Dastoor AP, Davignon D, Theys N, Van Roozendael M, Steffen A, Ariya PA. Modeling dynamic exchange of gaseous elemental mercury at polar sunrise. Environ Sci Technol. 2008 Jul 15;42(14):5183-8. doi: 10.1021/es800291w. PMID: 18754367.], which is available at: https://pubs.acs.org/doi/abs/10.1021/es800291w

measurements reported in the literature $(1,3)$. A detailed analysis of measurements at Alert for the years 1995-2002 is presented by Steffen et al. (9). Multiyear time series of GEM at Alert shows a consistent seasonal pattern with maximum variability and lowest median concentrations during spring $\left(1.39 \mathrm{ng} \mathrm{m}^{-3}\right)$ followed by lesser variability

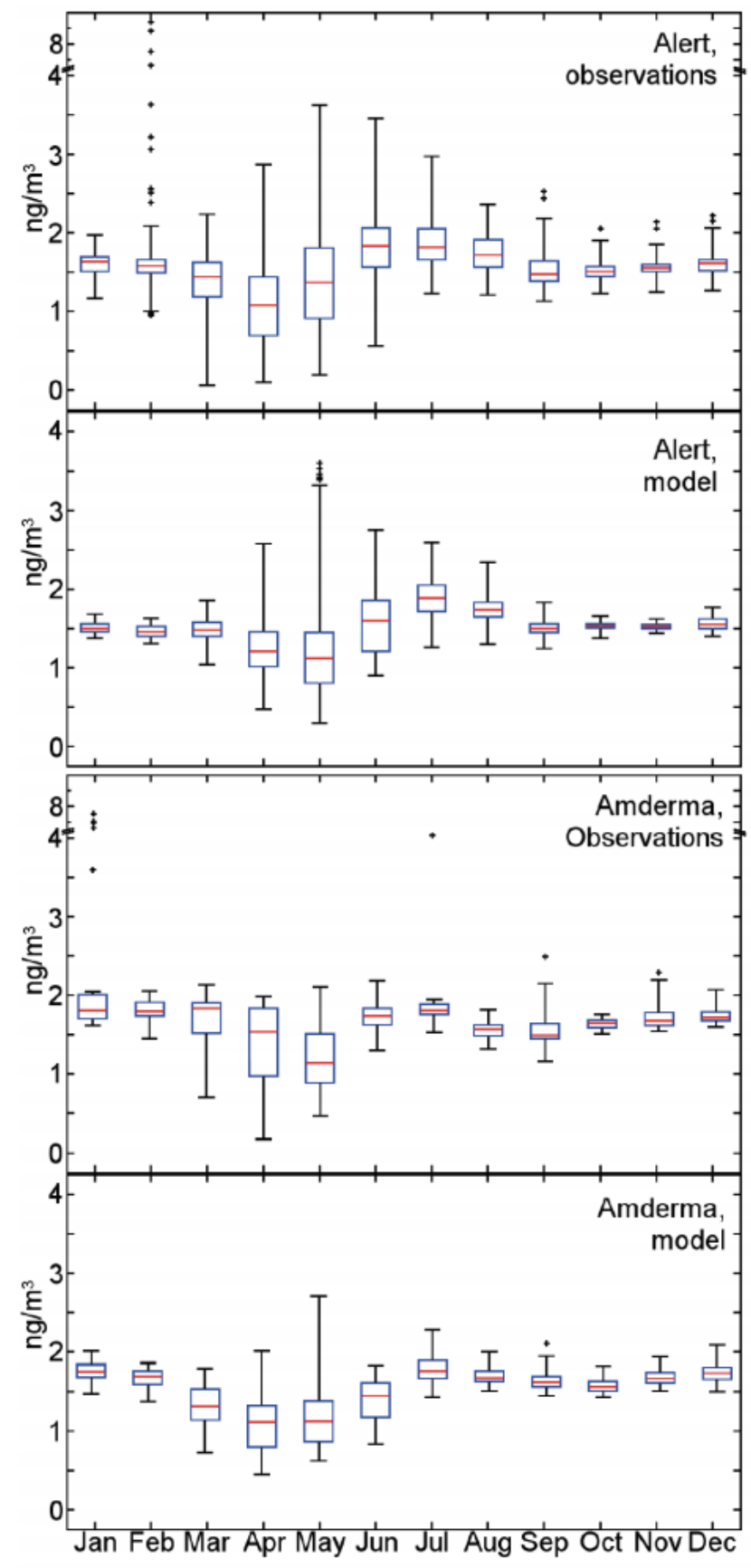

FIGURE 2. Observed (top) and modeled (bottom) interquartile range (25th percentile to 75 th percentile) and median (red line) of GEM concentrations ( $\mathrm{ng}$ of standard $\mathrm{m}^{-3}$ ) for each month for years 2002-2004 at Alert, Canada, and Amderma, Russia. The dashes at the ends of the vertical lines show the minimum and maximum values. The outlier data points are also shown on the plot. 
and maximum median concentrations in summer $\left(1.67 \mathrm{ng} \mathrm{m}^{-3}\right)$. Winter and fall show very little variance with background median concentrations of 1.63 and $1.54 \mathrm{ng} \mathrm{m}^{-3}$, respectively. Figure $\underline{1} \mathrm{a}-\mathrm{c}$ shows annual time series of modeled and measured concentrations of GEM for years 2002-2004. Rapid exchange of mercury related to AMDEs in springtime is seen in all 3 years in the model simulation and in the observation. Strong re-emission events are also observed and simulated in the late spring related to the higher surface temperatures. The model simulates the depletion events as well as the re-emission events, which are in good agreement with the GEM measurements. $\mathrm{Br}$ and $\mathrm{BrO}$ concentrations used in the model are climatological averages with dependence on the solar influx, boundary layer height, and surface temperature. Due to this limitation and the course resolution of the model, the model is expected to reproduce the seasonal cycle. However, despite these limitations, the model captures 1-2 weeks AMDE cycles and the interannual variability in GEM concentrations to some extent. These results suggest a significant role of meteorological processes such as transport, boundary layer height, solar radiation reaching ground, clouds, temperature inversion, and surface temperature in establishing AMDEs.

Seasonal cycle, monthly median, and the dispersion of the monthly GEM concentrations are evaluated at Alert and Amderma in Figure 2. The observed and simulated interquartile ranges at Alert represent years 2002-2004. At Amderma, the observed data is from January to October 2002 and October to December 2001 (9). Measured median concentrations of GEM at Alert (2002-2004) are $1.61 \mathrm{ng} \mathrm{m}^{-3}$ in winter, $1.34 \mathrm{ng} \mathrm{m}^{-3}$ in spring, $1.78 \mathrm{ng} \mathrm{m}^{-3}$ in summer, and $1.53 \mathrm{ng} \mathrm{m}^{-3}$ in fall. Model simulated average median surface air concentrations of GEM at Alert are $1.51 \mathrm{ng} \mathrm{m}^{-3}$ in winter, $1.35 \mathrm{ng} \mathrm{m}^{-3}$ in spring, $1.75 \mathrm{ng} \mathrm{m}^{-3}$ in summer, and $1.52 \mathrm{ng} \mathrm{m}^{-3}$ in fall. At Amderma, the median concentration of GEM are $1.75 \mathrm{ng} \mathrm{m}^{-3}$ in winter, $1.55 \mathrm{ng} \mathrm{m}^{-3}$ in spring, $1.71 \mathrm{ng} \mathrm{m}^{-3}$ in summer, and $1.63 \mathrm{ng}$ $\mathrm{m}^{-3}$ in fall from measurements (2001/2002) and $1.72 \mathrm{ng} \mathrm{m}^{-3}$ in winter, $1.18 \mathrm{ng} \mathrm{m}^{-3}$ in spring, $1.66 \mathrm{ng} \mathrm{m}^{-3}$ in summer, and $1.62 \mathrm{ng} \mathrm{m}^{-3}$ in fall from the model (2002-2004). The model is able to simulate the characteristic seasonal cycles at Alert and Amderma. Maximum variance in the springtime and near constant background of GEM during winter is seen at both sites. At Alert the maximum spread in GEM concentrations is observed in May, which is also simulated by the model. However, the average minimum median concentration for 2002-2004 is observed in April, whereas the model simulates minimum GEM concentrations in May. This is likely due to the bias in GOMEderived $\mathrm{BrO} / \mathrm{Br}$ concentrations in the model which are representative of the years 1996-2002. Steffen et al. (9) report average minimum median concentrations of GEM for 1995-2002 in the month of May, which is in agreement with our results. Although both sites exhibit similar seasonal cycle of GEM, the dispersion in GEM concentrations in spring and summer and the increase in GEM concentrations in summer both are less pronounced at Amderma compared to Alert. These differences can be attributed to the variations in the availability of sunlight, availability of halogen species, and the surface temperature at the two sites.

Monthly averaged boundary layer BrO concentrations in the model for March and May for the year 2003 are shown in Figure $\underline{3}$. BrO concentrations are maximum from March to May and reduce to very low levels in June. High oxidation of GEM from March to May in the Arctic is well correlated with BrO dynamics in the model (Figures 1 and 2). In March, BrO enhancement is in lower latitudes along the coasts, which progresses poleward in May with the shift in sunlight. In late spring, $\mathrm{BrO}$ concentrations are concentrated around the Polar cap, making it the most active region of mercury oxidation. Model simulation shows that mercury-depleted air masses from the Arctic Ocean are transported to the coastal regions during this period, causing extended periods of AMDEs. 
This is the peer reviewed version of the following article: [Dastoor AP, Davignon D, Theys N, Van Roozendael M, Steffen A, Ariya PA. Modeling dynamic exchange of gaseous elemental mercury at polar sunrise. Environ Sci Technol. 2008 Jul 15;42(14):5183-8. doi: 10.1021/es800291w. PMID: 18754367.], which is available at: https://pubs.acs.org/doi/abs/10.1021/es800291w
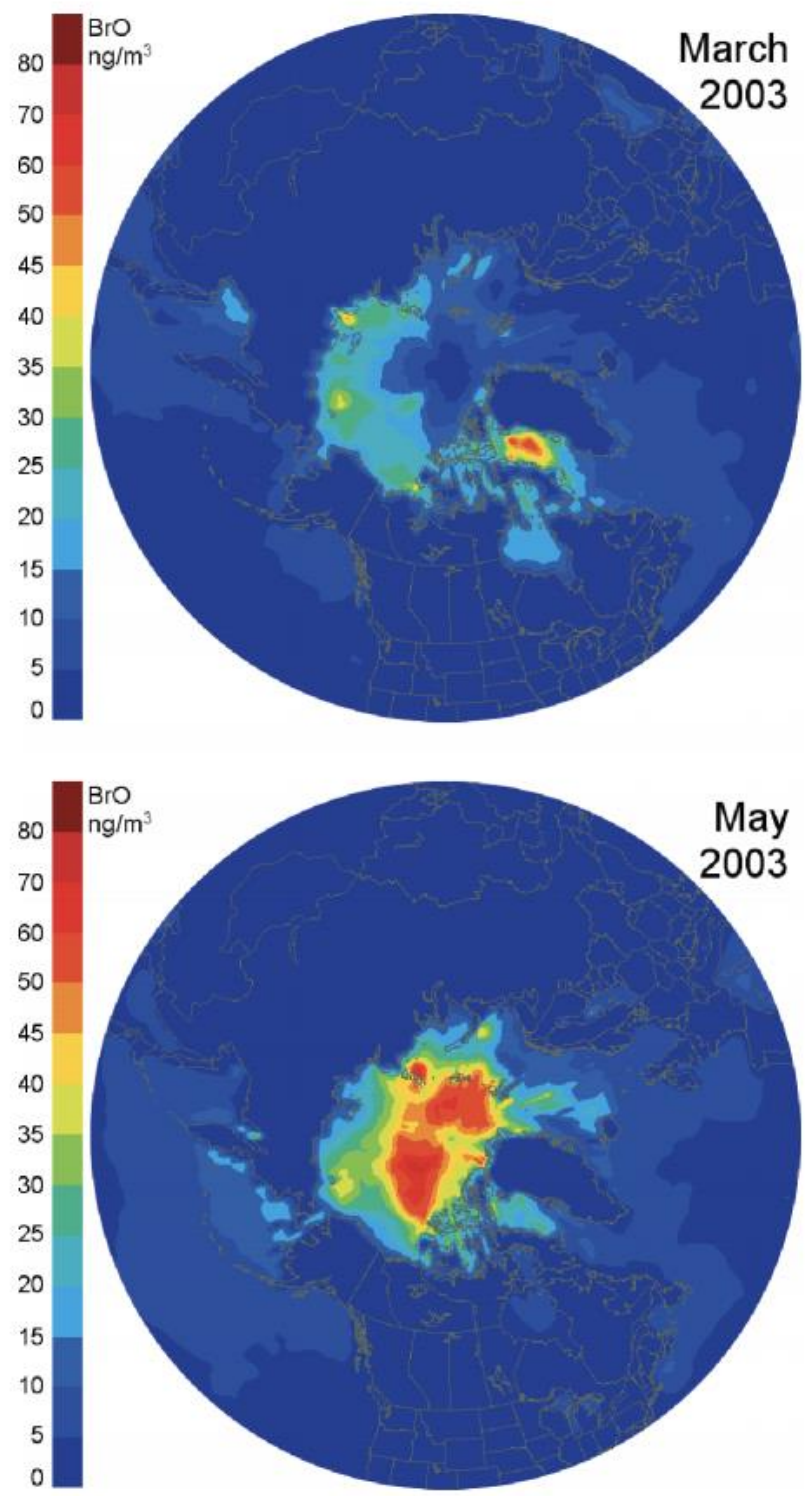

FIGURE 3. Monthly averaged $\mathrm{BrO}$ concentrations $\left(\mathrm{ng} \mathrm{m}^{-3}\right)$ in the model surface layer for March (top) and May (bottom) for 2003.

Total annual deposition of mercury for 2003 is shown in Figure $\underline{4}$. In addition to the high deposition around the anthropogenic source areas over the continents, significant deposition is simulated over the Arctic, Northern Pacific, and Northern Atlantic oceans. The highest deposition in the Arctic is seen in the region North of Alaska and Eastern Russia. AMDEs also contribute to higher deposition in Hudson Bay, Canada. Oxidation of GEM by $\mathrm{Br}$ and BrO is found to be dominant in the Arctic, whereas $\mathrm{Br}$ and $\mathrm{Cl}$ were found to be the most significant oxidizing species in MBL in the model. It is possible that some of the halogen-mediated oxidized mercury in MBL undergoes heterogeneous reduction on the aqueous sea-salt particles, reducing the net deposition to the oceans. The heterogeneous mercury chemical mechanism is not well understood, and further research is needed to assess the role of these reactions in MBL mercury cycling. At present, it is not possible to evaluate the deposition of mercury to the oceans due to the lack of observations. 


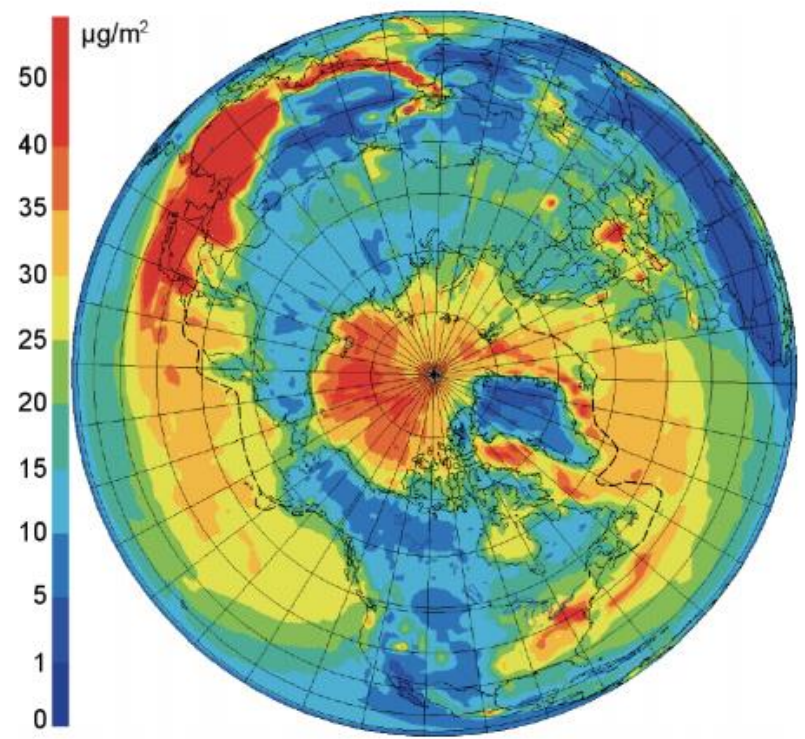

FIGURE 4. Annual mercury deposition for $2003\left(\mu \mathrm{g} / \mathrm{m}^{2}\right)$.

Net accumulation of atmospheric mercury is one of the key questions with respect to its environmental impact on the Arctic ecosystem. Model simulated monthly net accumulation of mercury within the Arctic Circle (North of $66.5^{\circ}$ ) is presented in Figure $\underline{5}$. Error bars show the interannual range for 2002-2004. The impact of AMDEs on the Arctic is clearly seen from March to May as maximum accumulation occurring during this period. A smaller peak in net accumulation is simulated in December, which is associated with the transport of mercury from European sources in the wintertime. Small net re-emission is simulated for July. Table 1 presents total deposition, re-emission, and net accumulation of mercury estimated by the model for January-February, March-May, June-August, and September-December within the Arctic Circle North of $66.5^{\circ}$. The sensitivity of the results to $\mathrm{Hg} / \mathrm{Br}$ chemistry is also presented in Table 1 . The interannual ranges for both set of simulations are shown in parentheses. Deposition, re-emission, and accumulation are highest for March-May, resulting in $\sim 46 \%$ contribution to the total annual accumulation of mercury in the Arctic. The model configuration using Donohoue et al. (7) $\mathrm{Hg}(0)-\mathrm{Br}$ reaction rates simulates less deposition of mercury in the spring due to the slower reaction rate coefficient compared to the Ariya et al. (5), resulting in lower estimates of mercury accumulation in the snow. The lowest interannual variability is simulated for September-December by the model, which is associated with the low variability in GEM concentrations during this period (Figure 2).

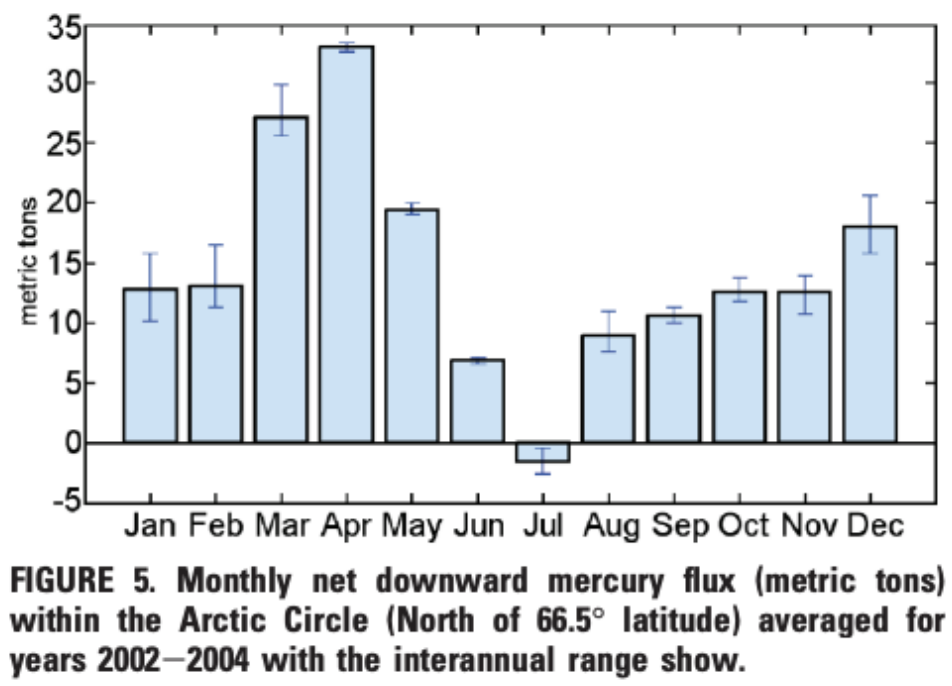


TABLE 1. Total Surface Mercury Fluxes (metric tons) within the Arctic Circle (North of $66.5^{\circ}$ Latitude) Averaged and Interannual Range for Years 2002-2004

\begin{tabular}{llclll} 
& \multicolumn{1}{c}{ Jan-Feb } & \multicolumn{1}{c}{ Mar-May } & Jun-Aug & Sept-Dec & annual \\
re-emission & $10(10)$ & $164(61-170)$ & $58(57-59)$ & $22(22-23)$ & $254(249-262)$ \\
deposition & $36(32-39)$ & $244(240-247)$ & $72(68-74)$ & $76(75-77)$ & $428(422-430)$ \\
accumulation $\mathrm{Hg}-\mathrm{Br}$ : Ariya & $26(22-29)$ & $80(77-83)$ & $14(12-16)$ & $54(54)$ & $174(168-181)$ \\
accumulation Hg-Br: Donohoue & $27(22-31)$ & $65(62-69)$ & $16(11-21)$ & $55(55)$ & $164(150-175)$
\end{tabular}

${ }^{a}$ The mercury accumulation from two model simulations using $\mathrm{Hg}-\mathrm{Br}$ reaction rates from Ariya et al. (5) and Donohoue et al. (7) are shown.

Brooks et al. (1) reported measured deposition, re-emission, and net gain fluxes of 1.7, $1.0 \pm 0.2$, and $0.7 \pm 0.2 \mu \mathrm{g}$ $\mathrm{m}^{-2}$ respectively, at Barrow, AK in a field campaign from March 25 to April 7, 2003. For this period, the estimates of deposition, re-emission, and net gain surface fluxes at Barrow using optimal configuration of the model are 1.8, 1.0 , and $0.8 \mu \mathrm{g} \mathrm{m}^{-2}$, respectively. The observed and model simulated median concentration of RGM for the campaign period is $125 \mathrm{pg} / \mathrm{m}^{3}$.

The development of the GRAHM mercury model is a significant advancement in understanding the role of AMDEs in the Polar Regions. However, there is a clear need for further research in improving the parametrizations of the mercury processes and comprehensive measurement data for evaluation of the models in the Polar Regions. Understanding of the processes involved in the production of high concentrations of bromine after sunrise in the Polar Regions is crucial for improving the modeling of halogen mercury chemistry. Continued research is needed in estimation of halogen mercury reaction rates and products, which represent one of the major uncertainties in model calculations. The role of heterogeneous chemistry in the Arctic as well as in MBL is also unclear at present. A better understanding of redox chemistry in snow and meltwater is needed for developing rigorous schemes for re-emission of mercury. Climate changes are likely to affect the halogen and mercury chemistry and mercury fluxes at the surface. This study is an important step toward developing a suitable atmospheric mercury model for assessing the impact of climate change on mercury fluxes in the Polar Regions.

\section{Author Information}

\section{Corresponding Author}

Ashu P. Dastoor - Air Quality Research Division, Science and Technology Branch, Environment Canada, 2121 Trans Canada Highway, Dorval, Quebec, Canada H9P 1J3, Belgian Institute for Space Aeronomy (BIRA-IASB), 3 Avenue Circulaire, B-1180 Brussels, Belgium, Air Quality Research Division, Science and Technology Branch, Environment Canada, 4905 Dufferin Street, Toronto, Ontario, Canada M3H 5T4, and Departments of Atmospheric \& Oceanic Sciences, and Chemistry, McGill University, 801 Sherbrooke Street West, Montreal, Quebec, Canada, H3A 2K6; Email: ashu.dastoor@ec.gc.ca

\section{Authors}

Didier Davignon - Air Quality Research Division, Science and Technology Branch, Environment Canada, 2121 Trans Canada Highway, Dorval, Quebec, Canada H9P 1J3, Belgian Institute for Space Aeronomy (BIRA-IASB), 3 Avenue Circulaire, B-1180 Brussels, Belgium, Air Quality Research Division, Science and Technology Branch, Environment Canada, 4905 Dufferin Street, Toronto, Ontario, Canada M3H 5T4, and Departments of Atmospheric \& Oceanic Sciences, and Chemistry, McGill University, 801 Sherbrooke Street West, Montreal, Quebec, Canada, H3A 2 K6 
This is the peer reviewed version of the following article: [Dastoor AP, Davignon D, Theys N, Van Roozendael M, Steffen A, Ariya PA. Modeling dynamic exchange of gaseous elemental mercury at polar sunrise. Environ Sci Technol. 2008 Jul 15;42(14):5183-8. doi: 10.1021/es800291w. PMID: 18754367.], which is available at: https://pubs.acs.org/doi/abs/10.1021/es800291w

Nicolas Theys - Air Quality Research Division, Science and Technology Branch, Environment Canada, 2121 Trans Canada Highway, Dorval, Quebec, Canada H9P 1J3, Belgian Institute for Space Aeronomy (BIRA-IASB), 3 Avenue Circulaire, B-1180 Brussels, Belgium, Air Quality Research Division, Science and Technology Branch, Environment Canada, 4905 Dufferin Street, Toronto, Ontario, Canada M3H 5T4, and Departments of Atmospheric \& Oceanic Sciences, and Chemistry, McGill University, 801 Sherbrooke Street West, Montreal, Quebec, Canada, H3A 2 K6

Michel Van Roozendael - Air Quality Research Division, Science and Technology Branch, Environment Canada, 2121 Trans Canada Highway, Dorval, Quebec, Canada H9P 1J3, Belgian Institute for Space Aeronomy (BIRAIASB), 3 Avenue Circulaire, B-1180 Brussels, Belgium, Air Quality Research Division, Science and Technology Branch, Environment Canada, 4905 Dufferin Street, Toronto, Ontario, Canada M3H 5T4, and Departments of Atmospheric \& Oceanic Sciences, and Chemistry, McGill University, 801 Sherbrooke Street West, Montreal, Quebec, Canada, H3A 2 K6

Alexandra Steffen - Air Quality Research Division, Science and Technology Branch, Environment Canada, 2121 Trans Canada Highway, Dorval, Quebec, Canada H9P 1J3, Belgian Institute for Space Aeronomy (BIRA-IASB), 3 Avenue Circulaire, B-1180 Brussels, Belgium, Air Quality Research Division, Science and Technology Branch, Environment Canada, 4905 Dufferin Street, Toronto, Ontario, Canada M3H 5T4, and Departments of Atmospheric \& Oceanic Sciences, and Chemistry, McGill University, 801 Sherbrooke Street West, Montreal, Quebec, Canada, H3A 2 K6

Parisa A. Ariya - Air Quality Research Division, Science and Technology Branch, Environment Canada, 2121 Trans Canada Highway, Dorval, Quebec, Canada H9P 1J3, Belgian Institute for Space Aeronomy (BIRA-IASB), 3 Avenue Circulaire, B-1180 Brussels, Belgium, Air Quality Research Division, Science and Technology Branch, Environment Canada, 4905 Dufferin Street, Toronto, Ontario, Canada M3H 5T4, and Departments of Atmospheric \& Oceanic Sciences, and Chemistry, McGill University, 801 Sherbrooke Street West, Montreal, Quebec, Canada, H3A 2 K6

\section{Acknowledgment}

We thank S. Gong for providing global sea-salt concentrations from CAM. We thank S. Venkatesh for his insightful comments on the manuscript.

\section{Literature Cited}

(1) Brooks, S.; Saiz-Lopez, A.; Skov, H.; Lindberg, S.; Plane, J.; Goodsite, M. The mass balance of mercury in the springtime arctic environment.Geophys. Res. Lett.2006, 33, L13812; 10.1029/ 2005GL025525.

(2) Shotyk, W.; Goodsite, M. E.; Roos-Barraclough, F.; Frei, R.; Heinemeier, J.; Asmund, G.; Lohse, C.; Hansen, T. S. Anthropogenic contributions to atmospheric $\mathrm{Hg}, \mathrm{Pb}$, and As accumulation recorded by peat cores from southern Greenland and Denmark dated using the 14C "bomb pulse curve".Geochim. Cosmochim. Acta 2003, 67 (21), 3991-4011.

(3) Steffen, A.; Douglas, T.; Amyot, M.; Ariya, P.; Aspmo, K.; Berg, T.; Bottenheim, J.; Brooks, S.; Cobbett, F.; Dastoor, A; Dommergue, A.; Ebinghaus, R.; Ferrari, C.; Gardfeldt, K.; Goodsite, M. E.; Lean, D.; Poulain, A.; Scherz, C.; Skov, H.; Sommar, J.; Temme, C. A synthesis of atmospheric mercury depletion event chemistry linking atmosphere, snow and water. Atmos. Chem. Phys. Discuss. 2007, 7, $10837-10931$. (4) Goodsite, M. E.; Plane, J. M. C.; Skov, H. A theoretical study of the oxidation of $\mathrm{Hg} 0$ to $\mathrm{HgBr} 2$ in the troposphere. Environ. Sci. Technol. 2004, 38 (6), 1772-1776.

(5) Ariya, P. A.; Khalizov, A.; Gidas, A. Reaction of gaseous mercury with atomic and molecular halogens, kinetics, products studies, and atmospheric implications.J. Phys. Chem. A 2002, 106, 7310-7320.

(6) Ariya, P.; Dastoor, A.; Amyot, M.; Schroeder, W.; Barrie, L.; Anlauf, K.; Raofie, F.; Ryzhkov, A.; Davignon, D.; Lalonde, J.; Steffen, A. Arctic: A sink for mercury. Tellus 2004, 56B, 397-403.

(7) Donohoue, D. L.; Bauer, D.; Cossairt, B.; Hynes, J. Temperature and pressure dependent rate coefficients for the reaction of $\mathrm{Hg}$ with $\mathrm{Br}$ and the reaction of $\mathrm{Br}$ with $\mathrm{Br}$ : A pulsed laser photolysispulsed laser induced fluorescence study. J. Phys. Chem. A 2006, 110, 6623-6632.

(8) Poulain, A. J.; Garcia, E.; Amyot, M.; Campbel, P. G. C.; Ariya, P. A. Mercury distribution, partitioning and speciation in coastal vs. inland High Arctic snow. Geochim. Cosmochim. Acta 2007, 71, 3419-3431.

(9) Steffen, A.; Schroeder, W.; Macdonald, R.; Poissant, L.; Konoplev, A. Mercury in the Arctic atmosphere: an analysis of eight years of measurements of GEM at Alert (Canada) and a comparison with observations at Amderma (Russia) and Kuujjuarapik (Canada). Sci. Total Environ. 2005, 342, 185-198.

(10) Poulain, A. J.; Lalonde, J. D.; Amyot, M.; Shead, J. A.; Raofie, F.; Ariya, P. A. Redox transformations of mercury in an Arctic snowpack at springtime. Atmos. Environ. 2004, 38, 6763-6774.

(11) Kirk, J. L.; St. Louis, V. L.; Sharp, M. J. Rapid reduction and reemission of mercury deposited into snowpacks during atmospheric mercury depletion events at Churchill, Manitoba, Canada. Environ. Sci. Technol. 2006, 40, 7590-7596. 
This is the peer reviewed version of the following article: [Dastoor AP, Davignon D, Theys N, Van Roozendael M, Steffen A, Ariya PA. Modeling dynamic exchange of gaseous elemental mercury at polar sunrise. Environ Sci Technol. 2008 Jul 15;42(14):5183-8. doi: 10.1021/es800291w. PMID: 18754367.], which is available at: https://pubs.acs.org/doi/abs/10.1021/es800291w

(12) Christensen, J. H.; Brandt, J.; Frohn, L. M.; Skov, H. Modelling of mercury in the Arctic with the Danish Eulerian hemispheric model. Atmos. Chem. Phys. 2004, 4, 2251-2257.

(13) Travnikov, O. Contribution of the intercontinental atmospheric transport to mercury pollution in the Northern Hemisphere. Atmos. Environ. 2005, 39, 7541-7548.

(14) Petersen, G.; Munthe, J.; Pleijel, K.; Bloxam, R.; Kumar, V. A comprehensive Eulerian modeling framework for airborne mercury species: Development and testing of the tropospheric chemistry module (TCM). Atmos. Environ. 1998, 32, 829-843.

(15) Dastoor, A. P.; Larocque, Y. Global circulation of atmospheric mercury: A modeling study. Atmos. Environ. 2004, 38, $147-161$.

(16) Pacyna, E. G.; Pacyna, J. M.; Steenhuisen, F.; Wilson, S. Global anthropogenic mercury emission inventory for 2000. Atmos. Environ. 2006, 40, 4048-4063.

(17) Mason, R. P.; Sheu, G.-R. The role of the ocean in the global mercury cycle. Global Biogeo. Cycles 2002, 16, 4, 1093, 10.1029/

2001GB001440

(18) Laurier, F. J. G.; Mason, R. P.; Whalin, L; Kato, S. Reactive gaseous mercury formation in the North Pacific Ocean's marine boundary layer: A potential role of halogen chemistry. J. Geophys. Res. 2003, 108, D17, 4529, doi: 10.1029/2003JD003625.

(19) Lin, C.-J.; Pongprueksa, P.; Lindberg, S. E.; Pehkonen, S. O.; Byun, D.; Jang, C. Scientific uncertainties in atmospheric mercury models I: Model science evaluation. Atmos. Environ. 2006, 40, 2911-2928.

(20) Van Roozendael, M.; Wagner, T.; Richter, A.; Pundt, I.; Arlander, D. W.; Burrows, J. P.; Chipperfield, M.; Fayt, C.; Johnston, P. V.; Lambert, J.-C.; Kreher, K.; Pfeilsticker, K.; Platt, U.; Pommereau, J.-P.; Sinnhuber, B.-M.; Tørnkvist, K. K.; Wittrock, F. Intercomparison of BrO Measurements from ERS-2 GOME, Ground-based and Ballon Platforms. Adv. Space Res. 2002, 29 (11), 1661-1666.

(21) Lehrer, E.; Ho" nninger, G.; Platt, U. A one dimensional model study of the mechanism of halogen liberation and vertical transport in the polar troposphere. Atmos. Chem. Phys. 2004, 4, 2427-2440.

(22) Theys, N.; De Smedt, I.; Van Roozendael, M.; Fayt, C.; Chabrillat, S.; Chipperfield, M.; Post, P.; Van Der, A. R. Total and tropospheric BrO derived from GOME and SCIAMACHY as part of the TEMIS project. Proceedings of the Envisat \& ERS Symposium, 2004.

(23) Hönninger, G.; Platt, U. Observations of BrO and its Vertical Distribution during Surface Ozone Depletion at Alert. Atmos. Environ. 2002, $36,2481-2489$.

(24) Sander, R.; Vogt, R.; Harris, G. W.; Crutzen, P. J. Modeling the chemistry of ozone, halogen compounds and hydrocarbons in the Arctic troposphere during spring. Tellus 1997, 49B, 522-532.

(25) Boudaries, H.; Bottenheim, J. W. Cl and $\mathrm{Br}$ atom concentrations during a surface boundary layer ozone depletion event in the Canadian high Arctic. Geophys. Res. Lett. 2000, 27 (4), 517-520.

(26) Gong, S. L.; Barrie, L. B.; Lazare, M. CAM: A Size Segregated Simulation of Atmospheric Aerosol Processes for Climate and Air Quality Models 2. Global sea-salt aerosol and its budgets. J. Geophys. Res. 2002, 107, 4779; 10.1029/2001JD002004.

(27) Von Glasow, R.; Sander, R. Modeling halogen chemistry in the marine boundary layer 1. Cloud-free MBL.J. Geophys Res. 2002, 107, 4341; 10.1029/2001JD000942.

(28) Lalonde, J. D.; Poulain, A. J.; Amyot, M. The role of mercury redox reactions in snow on snow-to-air mercury transfer. Environ. Sci. Technol. 2002, 36, 174-178

(29) Lalonde, J. D.; Amyot, M.; Doyon, M. R.; Auclair, J. C. Photoinduced Hg(II) reduction in snow from the remote and temperate experimental lakes area (Ontario, Canada).J. Geophys. Res. 2003, 108 (D6), 4200; 10.1029/2001JD001534.

(30) Fouquart, Y; Bonnel, B. Computations of solar heating of the earth's atmosphere: a new parameterization. Contrib. Atmos. Phys 1980, 53, $35-62$.

(31) Selin, N. E.; Jacob, D. J.; Park, R. J.; Yantosca, R. M.; Strode, S.; Jaegle', L.; Jaffe, D. Chemical cycling and deposition of atmospheric mercury: Global constraints from observations. J. Geophys. Res. 2007, 112, DO2308; 10.1029/2006JD007450. 